\title{
Short Communication \\ Attitude and perception toward anthrax among cattle owners in selected rural communities in Bangladesh
}

\author{
M.R. Karim ${ }^{1}$, M.A. Samad ${ }^{1}$, M.Z. Ali ${ }^{1}$, M.H. Rahman ${ }^{1}$, M.Z. $\operatorname{Hassan}^{1}$, M.A. Yousuf ${ }^{1}$, M.H. Kabir ${ }^{2}$, A.M. \\ Swapnil ${ }^{3}$ and M. Giasuddin ${ }^{1 *}$ \\ ${ }^{1}$ 1Animal Health Research Division, Bangladesh Livestock Research Institute, Savar, Dhaka-1341, \\ Bangladesh. ${ }^{2}$ System Research Division, Bangladesh Livestock Research Institute,Savar, Dhaka-1341, \\ Bangladesh. ${ }^{3}$ Sir Salimullah Medical College, Dhaka, Bangladesh.
}

\begin{abstract}
Anthrax is a zoonotic disease caused by spore forming Bacillus anthracis. Throughout the world, it causes illness in livestock, wildlife and sometimes secondarily infects humans and causes a major public health threat. The study was conducted to assess cattle owners' awareness, perceptions and attitudes toward anthrax. Data on awareness of anthrax, clinical signs of anthrax in animals and human, its routes of transmission and methods of prevention, the families' consumption habits of anthrax-infected carcasses, and other family activities that increase exposure to anthrax were collected using an interviewer-administered questionnaire. Overall, the level of awareness amongst the farmers for anthrax was $71.5 \%$. All of the farmers were aware that anthrax occurs in cattle, and $54 \%$ indicated the presence of unclotting blood oozing from natural orifices as a consistent finding in cattle that died of anthrax, whereas $71.2 \%$ of them indicated the presence of skin lesions as the most common sign of the disease in humans. The good efficacy of human anthrax treatment (62\%), slaughter of moribund cattle and selling of meat from cattle found dead to unsuspecting consumers (68\%), reluctance to lose animals (28\%), and forgetting about anthrax (46.4\%) were mentioned as the major reasons for consuming anthrax-infected carcasses. Of the respondents $79.2 \%$ of cattle owners indicated that they would not consume meat from cattle found dead, because they were discouraged by veterinary authorities, therefore introducing meat inspection services is likely to have a positive impact in preventing human anthrax outbreaks in selected areas of Bangladesh.
\end{abstract}

(Key words: Anthrax, cattle, community perception, cattle)

\section{Introduction}

Anthrax is a zoonotic disease caused by spore forming Bacillus anthracis (Woods et al., 2014). Throughout the world, it causes illness in livestock, wildlife, and sometimes secondarily infects humans and causes a major public health threat (Joyner et al., 2010). B. anthracis is a Gram-positive, capsulated, and sporeforming bacterium. The spores are very robust and can survive in suitable soil for several decades. In the Kruger National Park (Africa) B. anthracis spores have been isolated from animal bones estimated to be about 200 years old (Elvander et al., 2017). The ability of $B$. anthracis spores to survive outside the body is key for the ecology and evolution of this pathogen. The spores survive in soils rich in organic material and calcium and much better in alkaline soil with $\mathrm{pH}$ above 6.0 and a temperature of about $15^{\circ} \mathrm{C}$. In humans, $B$. anthracis can penetrate into the organism through micro-abrasions or cuts (developing a cutaneous form), via inhalation of the spores (Fulmonary form), and through the consumption of infected meat (intestinal form). Anthrax was reported in Bangladesh

*Corresponding author: mgias04@yahoo.com

Bang. J. Livs. Res. Special Vol. 21-25, 2018: P. 168-172, ISSN 1022-3851 
from 1980 to 1984 affecting both cattle and man (Samad et al., 1986; Ali et al., 2013), but it reemerged in 2009-2010 with wider involvement. The animal anthrax, locally known as 'Torka', is believed to have been enzootic in Bangladesh for a long time, and historically human outbreaks were always preceded by animal outbreaks (OIE, 2008). The Government of Bangladesh declared alert due to a sudden explosive outbreak of anthrax in 2010 that hit 12 districts and affected 607 people. The outbreak was investigated and thought to have been caused by the slaughter of infected cattle and selling or eating contaminated meat. The outbreak was most prevalent in the districts of Pabna, Sirajganj, Rajshahi, Kushtia and Tangail, which have greater cattle populations (Ahmed et al., 2001; Khokan et al., 2017; Bary et al., 2018). Health and livestock officials in Bangladesh have expressed great concern over a fresh outbreak of human anthrax prevailed in up to June 2016, mostly affecting Ullapara, Shahzadpur and Kamarkhand upazilas of Sirajganj (125 cases) and Pabna (32 cases) (Talukdar et al., 2017). Additionally, districts of Bogura, Meherpur and Tangail had cases of anthrax. The study was conducted to assess cattle owners' awareness, perceptions, and attitudes toward anthrax, risk factors for the spread and the disease persistence.

\section{Materials and Methods}

The study was conducted in two villages (Alokdiar and Potajia) of Shahjadpur Upazila under Sirajgonj district. A semi-structured, open-ended questionnaire was developed to gather information on the awareness, perceptions, and attitudes towards anthrax by farmers. Interviews of farmers using the semi-structured questionnaire were done using the local vernacular language of each of the selected villages. As a way of not interfering with local important rural activities, farmers were interviewed on 'sacred' days after consultation with the local veterinary extension officers and the village heads.

The questionnaire was designed to obtain information on known awareness of anthrax, causative agent of anthrax, animals affected, animal and human clinical signs of anthrax, time of occurrence of anthrax, and routes of transmission of the disease. Respondents were also asked about consumption habits, family and community-based activities that increase risk of contracting anthrax, treatment-seeking behavior, and prevention of anthrax. Each respondent's responses were recorded and entered into a Microsoft Excel database. Data analysis was carried outusing SPSS 16.0 for Windows to generate descriptive statistics (frequencies/proportions) related to the cattle owners' awareness of anthrax, causative agent of anthrax, animals affected, animal and human clinical signs of anthrax, time of occurrence of anthrax, routes of transmission of the disease,consumption habits, family and community-based activities which increased risk of contracting anthrax, treatment- seeking behavior, and prevention of anthrax.

\section{Results and Discussion}

In Bangladesh, Sirajgonj and nearby district is the mostly anthrax prevalent area (Ahmed et al., 2010; Biswas et al., 2011). The results of the survey revealed that $70 \%$ respondents were not aware on anthrax that is why they slaughtered diseased animals. Hassan et al. 
(2015) surveyed that about $87.5 \%$ people of Shahajadpur Upazilla of Sirajgonj district were not aware of anthrax. Awareness among the community might have increased due to frequent campaigning about anthrax from public and non-government organizations (Talukdar et al., 2017).

When asked specifically about anthrax, less than $30 \%$ of the farmers knew the causative agent of the disease. All farmers Alokdiar and Potajia knew that anthrax occurs in cattle. When questioned on clinical signs that suggest anthrax in animals, farmers mentioned the presence of blood oozing from natural orifices (54\%), unclotting blood $(8 \%)$, sudden deaths (38\%), and rapid decomposition (14\%) (Table 1). In humans, the presence of skin lesions $(71.2 \%)$ was

Table 1. Awareness and attitude toward anthrax among cattle owners

\begin{tabular}{lll}
\hline Variables & Response & Number (\%) \\
\hline \multirow{2}{*}{ Clinical signs in animals } & Sudden death & $95(38)$ \\
\cline { 2 - 3 } & Blood from natural orifices & $135(54)$ \\
\cline { 2 - 3 } & Presence of unclotted blood & $20(8)$ \\
\cline { 2 - 3 } & Rapid decomposition & $35(14)$ \\
\hline \multirow{2}{*}{ Clinical signs in humans } & Skin lesions & $178(71.2)$ \\
\cline { 2 - 3 } & Diarrhoea & $45(18)$ \\
\cline { 2 - 3 } & Vomiting & $30(12)$ \\
\hline Transmission routes & Eating infected meat & $165(66)$ \\
\cline { 2 - 3 } & Skinning of infected carcasses & $190(76)$ \\
\hline Treatment-seeking Behavior & Clinic/hospital & $215(86)$ \\
\cline { 2 - 3 } & Traditional healer & $20(8)$ \\
\hline Prevention of anthrax & Burning or burying infected carcasses & $115(46)$ \\
\cline { 2 - 3 } & Vaccination & $160(64)$ \\
\hline
\end{tabular}

Table 2. Responses of meat consumption behavior of cattle owners and family activities

\begin{tabular}{|c|c|c|}
\hline Variable & Response & Number $(\%)$ \\
\hline \multirow{3}{*}{$\begin{array}{l}\text { Reasons for not eating meat } \\
\text { from animals found dead }\end{array}$} & Not allowed by veterinary authorities & $198(79.2)$ \\
\hline & Religion & $125(50)$ \\
\hline & Afraid of contracting Diseases & $112(44.8)$ \\
\hline \multirow{5}{*}{$\begin{array}{l}\text { Reasons for eating meat from } \\
\text { animals found moribund }\end{array}$} & Could not just afford to lose the animal & $165(66)$ \\
\hline & $\begin{array}{l}\text { Reportedly slaughtered the moribund } \\
\text { animal to salvage meat }\end{array}$ & $170(68)$ \\
\hline & Long time since eating meat & $143(57.2)$ \\
\hline & Price of meat in local butchery too high & $168(67.2)$ \\
\hline & Had forgotten about anthrax & $116(46.4)$ \\
\hline \multirow{2}{*}{$\begin{array}{l}\text { Reasons for eating meat from } \\
\text { animals suspected to have died } \\
\text { of anthrax }\end{array}$} & Could not just afford to lose the animal & $70(28)$ \\
\hline & $\begin{array}{l}\text { Would go to hospital once skin lesions } \\
\text { developed and treatment was effective }\end{array}$ & $155(62)$ \\
\hline
\end{tabular}


identified as the most predominant sign suggestive of anthrax, whereas less than $20 \%$ of the farmers reported diarrhoea and vomiting as other clinical signsof anthrax in humans (Table 1). Skinning (76\%) and eating $(66 \%)$ infected carcasses were mentioned as important routes of transmission (Brooks and McGregor, 2018). A very high proportion $(86 \%)$ of the farmers indicated that they would refer a sick family member who had consumed an anthrax carcass to the clinic or hospital, whereas a very small percentage $(8 \%)$ would send to a traditional healer. Over $60 \%$ of the farmers were aware of anthrax preventive measures, such as vaccination. Most farmers (85\%) indicated that the disease occurs during the dry season, is agreed with Hassan et al. (2015).

Women were indicated as generally responsible for preparation and cooking $(85 \%)$ of the meat, whereas men were responsible for slaughtering (88\%), skinning $(92 \%)$ and butchering (75\%). Table 2 shows the farmers' reasons for cattle meat consumption behavior. Prohibition by veterinary authorities (79.2\%), religion $(50 \%)$, and fear of contracting diseases (44.8\%) were the indicated reasons for not consuming meat from cattle that were found dead. The reasons for eating meat from cattle that died of unknown causes were: could not just afford to lose the carcass (66\%), 'slaughtered' a moribund animal to salvage meat for consumption and/or sale (68\%), long time since ate meat $(57.2 \%)$, price of meat from local butchery was too high (67.2\%), and had forgotten about anthrax (46.4\%). When asked for the reasons for consuming meat from cattle suspected to have died of anthrax, $62 \%$ of the respondents indicated that they would go to the hospital once they developed skin lesions and the treatment was effective, $28 \%$ indicated that they could not just afford to lose the animal.

\section{Conclusion}

Continual anthrax outbreaks in animals and humans occurs due to slaughtering of anthrax-infected animals and disposing of slaughtering waste and carcasses in environments where ruminants live and graze, combined with limited vaccination. Of the respondents $79.2 \%$ of cattle owners indicated that they would not consume meat from cattle found dead, because they were discouraged by veterinary authorities, therefore introducing meat inspection services is likely to have a positive impact in preventing human anthrax outbreaks in selected areas of Bangladesh. Awareness creation among the farmers and consumers; and long-term vaccination coverage for at-risk animal populations may reduce anthrax infection.

\section{References}

Abdrakhmanov, S.K., Mukhanbetkaliyev, Y.Y., Korennoy, F.I., Sultanov, A.A., Kadyrov, A. S., Kushubaev, D.B. and Bakishev, T.G. 2017. Maximum entropy modeling risk of anthrax in the Republic of Kazakhstan. Preventive Veterinary Medicine. 14: 149-157.

Ahmed, B.N., Sultana, Y., Haque, M.M., Karim, M.R., Rahman, D. 2001. Bacillus anthracis: an agent of biological weapon. JOPSOM. 20(2):45-50.

Ahmed, N., Sultana, Y., Fatema D.S.M, Ara K., Begum N., Mostanzid S.M., Jubayer S. 2010. Anthrax: An emerging zoonotic disease in Bangladesh. Bangladesh Journal of Medical Microbiology, 4: 46-50.

Ali, M.Z., Sultana, S., Rahman, M.T. and Islam, M.S. 2013. Economics of fertility 
management of small holding dairy farms in Bangladesh. Iranian Journal of Applied Animal Science. 3(3): 509-512.

Bary, M.A., Ali, M.Z., Chowdhury, S., Mannan, A., Azam, M.N.E., Moula, M.M., Bhuiyan Z.A., Shaon, M.T.W., Hossain, M.A. 2018. Prevalence and Molecular Identification of Haemoprotozoan Diseases of Cattle in Bangladesh. Advances in Animal and Veterinary Sciences. 6(4): 176-182.

Biswas, P.K., Islam, M.J., Shil, S.K., Chakraborty, R.K., Ahmed, S.S.U., Christensen, J.P. 2011. Risk factors associated with anthrax in cattle on small holdings. Epidemiology and Infection. 140: 1888-1895.

Brooks Tim, and Alastair McGregor. 208. Anthrax. In Case Studies in Infection Control, pp. 1-10. Garland Science, 2018.

Elvander, M., Persson, B., Sternberg Lewerin, S., 2017. Historical cases of anthrax in Sweden 1916-1961. Transboundary and Emerging Diseases, 64, no (3): 892-898.

Hassan, J., Ahsan, M., Rahman, M., Chowdhury, S.M.Z.H., Parvej, M. and Nazir, K.H.M., 2015. Factors associated with repeated outbreak of anthrax in Bangladesh: qualitative and quantitative study. Journal of Advanced Veterinary \& Animal Research. 2(2): 158-164.

Joyner, T.A., Lukhnova, L., Pazilov, Y., Temiralyeva, G., Hugh-Jones, M.E., Aikimbayev, A., 2010. Modeling the potential distribution of Bacillus anthracis under multiple climate change scenarios for Kazakhstan.PLoS One 5: e9596.
Khokon, M.S.I., Azizunnesa, M., Islam, M.M., Chowdhury, K.B., Rahman, M.L. and Ali, M.Z., 2017. Effect of mastitis on post-partum conception of cross bred dairy cows in Chittagong district of Bangladesh. Journal of Advanced Veterinary and Animal Research.4(2): 155-160.

OIE. 2008. OIE listed diseases and other diseases of importance to international trade. Part-2, Chapter 2.1.1.-Anthrax; pp 135-144.

Samad, M.A., Hoque, M.E. 1986. Anthrax in man and cattle in Bangladesh. Tropical Medicine and Hygiene. 89(1):43-45

Talukdar, F., Sabrina, M., Sultana, R. and Sazzad, M., 2018. Outbreak of Cutaneous Anthrax in Kalukhali upazilla, Rajbari district, Bangladesh 2017. Iproceedings. 4(1): p.e10644.

Woods, C.W., Ospanov, K., Myrzabekov, A., Favorov, M., Plikaytis, B., Ashford, D.A., 2004. Risk factors for human anthrax among contacts of anthrax-infected livestock in Kazakhstan. American Society of Tropical Medicine and Hygiene. 71: 48-52. 